$2 \cdot 5 ，$ Cr $0.5 \%$ を入れると 550 になる。温度は 1450

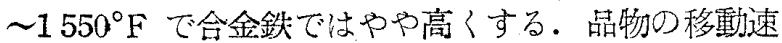
度は 4 7 in $/ \mathrm{mn}$ ，トーチ先端と品物との距離は 0.55 〜 0.65 in, 酸素アセチレンガス消費量は硬化深さ $3 / 16^{\prime \prime}$, 移動速度 $4 \mathrm{in} / \mathrm{mn}$, でアセテレン $28 \mathrm{ft}^{3} / \mathrm{in}^{2}$, 酸素 30 $\mathrm{ft}^{3} / \mathrm{in}^{2}$ (火口径 $4^{\prime \prime} \phi$ ) である. 水喛射量は $60 \sim 100 \mathrm{psi}$ で肉薄物では補助ゼットで火炎前方輴水し加熱面を

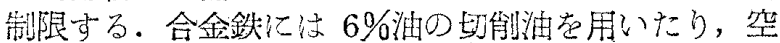
気を用いることがある。火炎搜化で优外表より少し内 がかたささか高々なる。かムシャフト，プレス用ダイス 等に利用洒値は大である。

[一个岩健晃]

\section{$621.74: 658.564$}

[112] 鋳物工場楼械化の進步 [R.J. Geitman, Foundry, 1954-8, Vol. 82, No. 8, p. 70 75, 216,

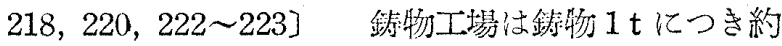
150〜200七の材料苍取技うので機諓化に対しては材料

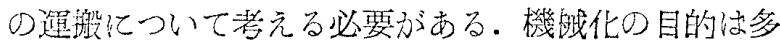
量生统，低価格，作業状態の改善であって，融通性の

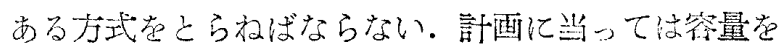

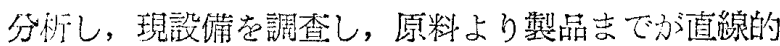

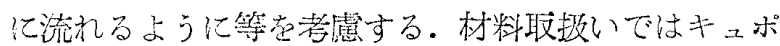
ラへの原料㵏入，スラッグ連搬，コークス取圾い等に

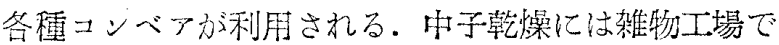
は batch type の师がよい。連続少は中子種数の多？ ない特が丸い. 大工場ではトロリーコンベア，小工場 で流トラック在用いる。砂処理隹大工場で宗 skeout hopper, magnetic pulley, backet elevator, sand bin, muller, belt conveyor 式尼朋い，小工場では tractor shovel で oscillating conveyor 上に持ってきて砂よ 品物を分離し形少を elevator, measuring hopper, muller を通し tractor shovel で分配する。琹达汸注湯 は一方化連続式，一方に Pallet 式を偣用して融通性 をもたせる。本文仙以上の外:三の点についても写真 によって機珴化に対する注意を逝べている。

$$
\text { [下を岩健児] }
$$

\section{$621.791 .75: 621.134-222$}

\section{[119]登気㙨関車の電弧溶接鋼板シリンダの製作}

[Mario Voltolini \& Egisto Martelloni, I. I.W. Annual Meeting 1954, Public Session on Welding in Rail and Road Transport, p. 1 5, 図 5] 戦 後イタリヤで機関車シリンダを鏻造で作る代りに浴葌

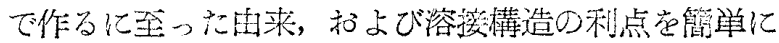

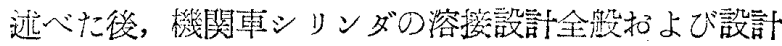

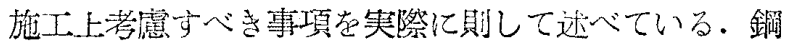
板の板㿞蚛 $15 \mathrm{~mm}$ のテャンネル以外はすべて $28 \mathrm{~mm}$ で，图面にはすべての溶接順序を記入し，また強くか つ岡性の大なる部材の溶接に恃特胡の順序をきめた。 㠾合せ継琹ではできるだけXグルーブを用い，Vグル

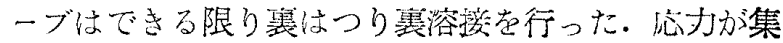

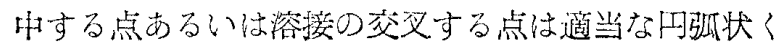
り穴を作って避けるようにした，収繀扔よびひずみ量 が定量的に予想できなかったので，最後の組立に用う る溶接量在鼠小にするため，部分組立をできるだけ多 くした。溶稳はなるべく下用溶揬で行う段取を研究し また溶接作栄は中心部から外部にすなわち㧦束部から 自由端に间，て進められた。市る場合には局部的予熱
扣よびバックステッブ溶接法を用い，また継手が非常 に拘束を受けると考えられる時には適当なピーニング 老行った．更に泠却速度が非常に速いと考えられるほ ご部材が肉厚に集結される場合の継手には匴を行っ た. 後熱は 8 時間加熱し， $650^{\circ} \mathrm{C}$ 亿2 時間保ち，40時 間で紷却した。全重量 $4500 \mathrm{~kg}$. 完成した最初のシり ンダはほとんど異常なく 1 年まど使用されている。

[太国舀三郎]

\section{$621.565: 532.55$}

\section{[114]フレオン柔配管における和降下の決定法}

[W.L. Holladay, Refr. Engg., 1954-9, Vol. 62, No. 9, p. 55 61, 図 7, 郝 2] Fanning O式 $\Delta p_{100}=\frac{1 \cdot 21 f w^{2} V}{d^{5}}$ 基とし, フレオンー12, フレホ

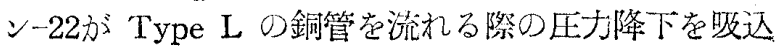
管, 吐出管; 液管, 蒸発器の4 種について区表わし ている。

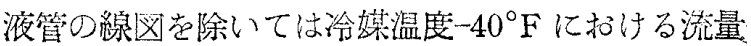
に対する直管 $100 \mathrm{ft}$ 当りの圧力降下゙を psi で表わし 加つ種々の冷媒温度 $\left(50^{\circ} \mathrm{F} \sim-120^{\circ} \mathrm{F}\right)$ 亿刘する補正索 なしまたフレオン -12 とフレオン 22 とについて別 «の線囯を作っているが，液管については共用の線园 を低している。

〔森永 勝之]

\subsection{7 : 697.4}

[115〕各種逥水混合弁の構造〔W. Zimmermann, Heiz. Lüft. Haust., 1954-3, Bd. 5, Ht. 3, s. 77

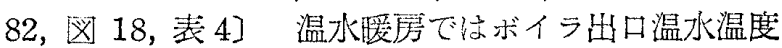
$90^{\circ} \mathrm{C}$ 亿対して設計名るが，䁔房期間の大部分は設計 負荷よりも著しく軽急荷で使われるから，ボイラ出口: 温度は最低 $35^{\circ} \mathrm{C}$ までの箕䎳を变動する。ところが 炊等や浴用に泣一定の高温水か泌要であるし，宗た，

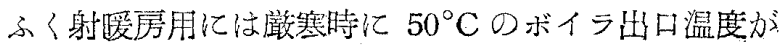
必裂でする。これらの用途测して別々のボイラを使 用しないで㷉一のボイラを使用するには，ボイラから 送出す水温は一定として扣き，てれ亿適量の還り水を 混ぜればよい，送出管と翌り管と普通の弁でつない でも十分な結鼠偟ら行ないが，特别に設語した還水

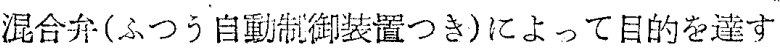
ることができる、混合後温度が $100^{\circ} \mathrm{C}$ 以下の場合には 普通型，100ないし $150^{\circ} \mathrm{C}$ の場合に恃殊型力使われ るふゔ，いずれも多数市場に出ている。本交には弁の構 造のみでな?，配管法や負荷变動に対する応答状洗も， 説明してある.

[石谷 清幹]

\subsection{4}

[116]開放地用ガスだきふく射桨房器〔H.Bulnheim, Heiz. Lüft. Haust., 1954-3, Bd. 5, Ht. 3, s. 83 . ～86, 図 10]飲食店入口や飾塋前の街路を子く射 䁔房した例は徒来加らあが，一つの街路全体をふく 射暖房したのは Bremen の Sögestraße がはじめて

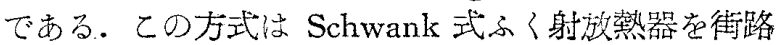
の上空にならべて，通行者の頭上から赤外ふく射線を 放射させたものである。京く射線结空気には吸収され

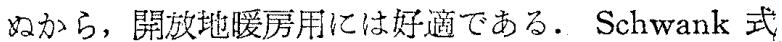
放蓺器淰ブンゼンバーナと触媒板より成り, 都市ガス の然烧により触媒板を $800 \sim 900^{\circ} \mathrm{C}$ に加熱するもので ガス発䓡量の 50\% 強をふく射で放熱する. Bremen

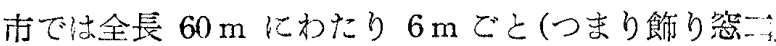


つごと）に地上 $3.2 \mathrm{~m}$ の高さに設けた。るの下を步 行する人が歩行につれてあたたかみのリズム芷適当に

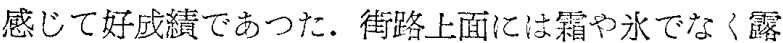
者生じ，一そうあたたかそうな感じを沿えた。露の日

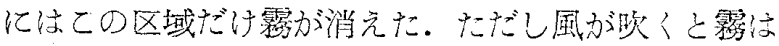
完全に好消隇しないが，霛がうすくなるだけでも心理 的には消減の上うに感じられた。【石谷 潜幹】

\subsubsection{2}

〔117〕海水の冷谏脱塩法 〔Thomas G. Thompson \& Kurt H. Nelson, Refr. Engg.,1954-7, Vol. 62,

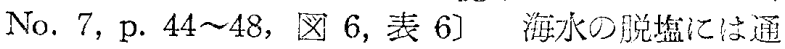

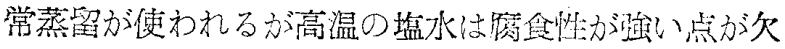
点である. 冷涷捝塩法は将来性があると思われるが基

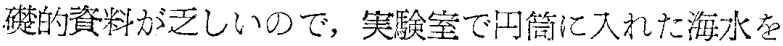

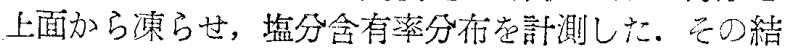
果によると，初期に形成される水は塩水含存量が藷し くすくない（塩素量 70〜130 ppm）功，再形成された

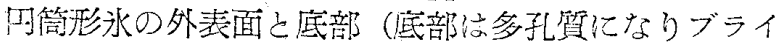

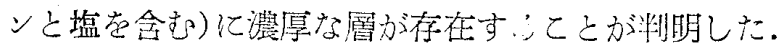
したがって形成された承觉等温でとかす時に最初に出

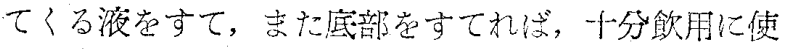
える水分得られる。 [不谷 清幹]

\section{$621.929: 66.022$}

[118]固体の乾式混合 [L.T. Work, Chem. Eng. progress, 1954-9, Vol. 50, No. 9, p. 476 479, 网 9] =ューヨークのコンサルティンダ・エンジニヤ である等煋が湿合の実際的問題苍とりあっかってい る. 混合を一つの単位操作として独故したものとのみ 访考えないで，工業装置全体として，才なわちプロ七 不全体として考えるべきであるてとる示している。た

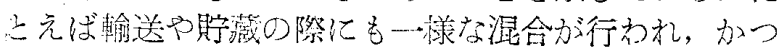
保たれるように注意ずべざ，党に遊の分離動作が起 ら欢ようし掛けることが必要である。湿合㴗要求の程

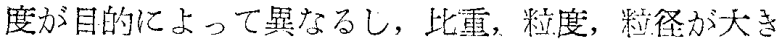

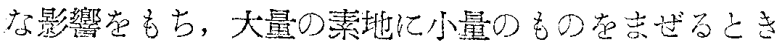
沈大量の才を少しずつ加えてりくのがよい，普通の 回分式の混合穖の他に連続式として各種の粉砕機やフ

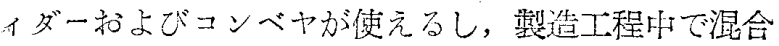

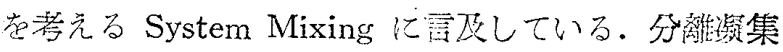
を防ぐために混合を最終工程で行うとか，乾燥してわ ら混合するとか，混合直後にわざと小埃に䝷集させて しまうためにしめらしたり粘着戍を少量入れることる 行われるとのベている。

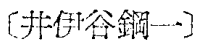

\subsubsection{3:669.14}

[119]農業機械之鎡材 [C. J. Scranton, W.C. Bliesener, W.H. Nordenson, H. W. Browall, Agr. Engg., 1953-10, Vol. 34, No. 10, p. 695 701 (708)] アメリカの装業機㳦の生洼関係する 3 人の專門家 が，それぞれの立場汃らの経験にもとづいて，使用す る鋼材に刘する要求をのへ，最後に鋼の生産に関する 専門家の一人が，それに対する意見希のべている。

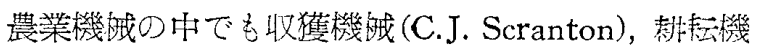
栈(W.C. Bliesener) は，年間党通じて使用する期間が 短汃人，雷量が小でコストも最小である事放望まれ，

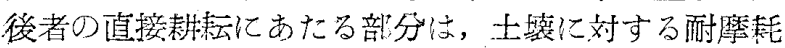

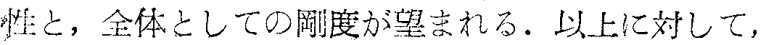

トラクタ（W.H. Nordenson）は，はたけ作業の活办 に，定置してをの動力安利用する作業にも使われ，年

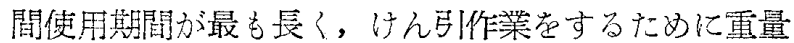
が大で，乙かも，製作コストの小さいことが望まれ， 前…者と全くこの趣を逆にする.

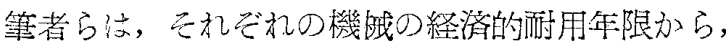

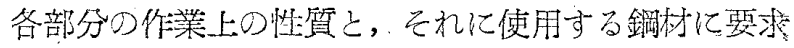
される性質をのべている。更に，をるって望んている こと纺，素材の規格の統一である。

しえし，大小さまざまの農羔機㭜のメ一カ，特に各

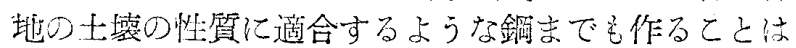

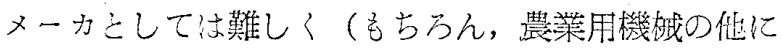

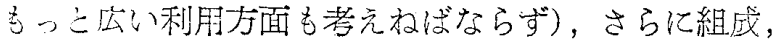
加工法，機峨的性質，形の異なった各種多様の鎘材を 需姴者心要求に巵じるように分類することは難しい (W.H. Browall).

しかし，なるべく程類を少くして，需嬖㨋の便を計

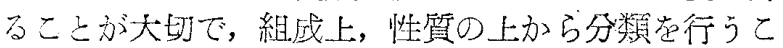
とに然力が払われ，SAE，ASTM，AISIなどのわけ

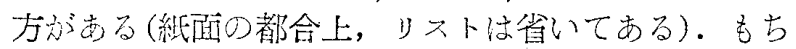
ろん，いろい万の諘論专盛んに行われている。

[犦原定郎]

\section{$658.562: 519.2$}

〔120]母集団の平均を管理するねめの最も経済的な 試料の大きさについて [H. Weiler, Ann. Math. Stat., 1952, Vol. 23, No. 2, p. 247〜254, 表 3]

集过の平均值苟管理する管理図では小さい試料を ひん繁に取ることも，大きい試料をさ活どひん繁でな

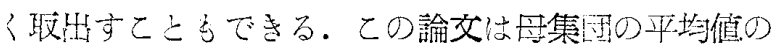

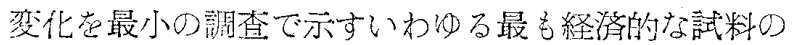

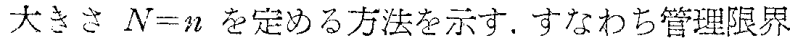

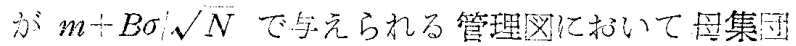
平均徝が $m$ 加ら $m+k \sigma$ に変化したとき, 最邀の $N$ $=n$ 它一船に $n=Q^{2} / k^{2}$ の形で与元られ，普通用いら れる $B=3 \cdot 09,3,2.53,2 \cdot 33$ の各埸合に対し $Q^{2}=$

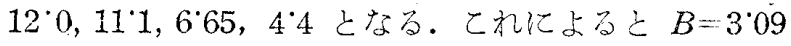
志たは3の場合普通用いられる夫きさ10 以下の試料 缩 $k \geqq 1$ 亿䞑して適当であって $k<1$ のとき依もっ 上大きな試料の方方よいことになる。乙かし曆别の效

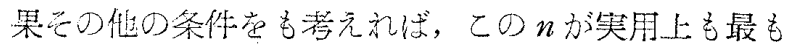
よいと一概に注言えない。また複式管理园に言及し，

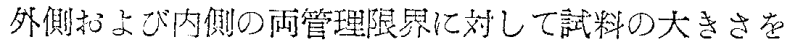
異にすべさと打よび使用上の注意を与えている。

\section{1-52:681.2}

[不田誠]

[121] 計器工業之周波数応答法 〔Rufus Oldenburger, I.S.A.J., 1954, Vol. 1, No. 9, p. 157 160,

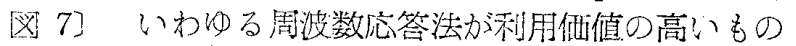

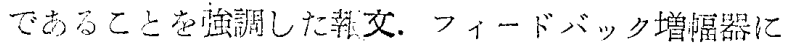

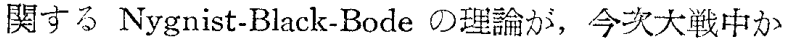

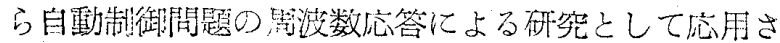
れて大きな成果を与えたこと察列で示したのち，周

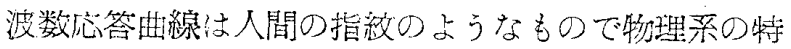

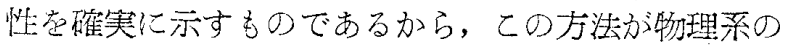
診断に用いられることをガスタービンの速度制御に関 する筆者の経験を例にひいて説いている。このほかい

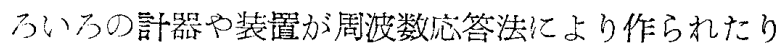

